GEOLOGICAL SURVEY CIRCULAR 543

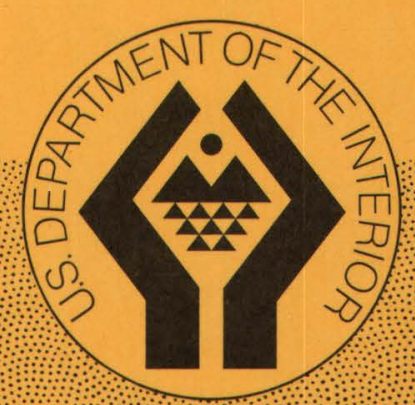

Distribution of Gold, Tellurium Silver, and Mercury in Part of the Cripple Creek

District, Colorado 



\section{Distribution of Gold, Tellurium Silver, and Mercury in Part of the Cripple Creek District, Colorado}

By Garland B. Gott, J. Howard McCarthy, Jr. Gordon H. VanSickle, and John B. McHugh

GEOLOGICAL SURVEY CIRCULAR 543

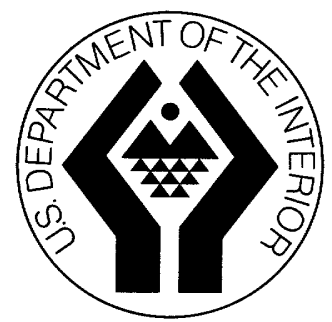


United States Department of the Interior

STEWART L. UDALL, Secrefary

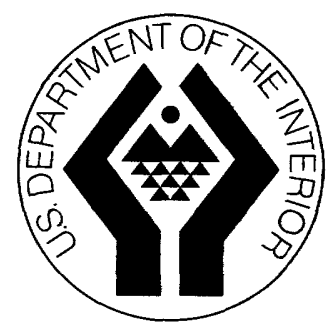

\section{Geological Survey}

William T. Pecora, Director

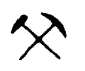

First printing 1967

Second printing 1967

Third printing 1969 


\section{CONTENTS}

Page Page

Abstract -

1 Anomalous area -....................................

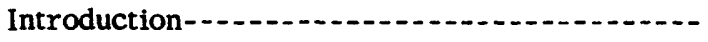

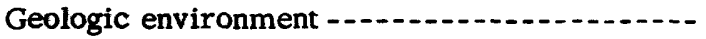

Material sampled-_.....-...-

1 Distribution of gold, silver, tellurium, and

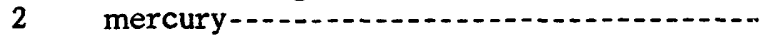

2 Economic potential

2 References -.................

\section{ILLUSTRATIONS}

Figure 1. Index map of Colorado showing area of this report-

2. Map showing sampled localities and area of figures 3-7

3-7. Detailed maps showing concentration of gold, silver, tellurium, and mercury

at each locality sampled:

3. Gold, average concentration -

4. Gold, highest concentration -

5. Silver, highest concentration-1.-

6. Tellurium, highest concentration -

7. Mercury, highest concentration -

\section{TABLE}

Page

Table 1. Abundance of gold, silver, tellurium, and mercury in the earth's crust, in volcanic rocks of the entire Cripple Creek district, and in rocks of the area of the gold anomaly discussed in this report 


\title{
Distribution of Gold, Tellurium, Silver, and Mercury in part of the
}

\section{Cripple Creek district, Colorado}

\author{
By Garland B. Gott, J. Howard McCarthy, Jr., Gordon H. VanSickle, and John B. McHugh
}

\begin{abstract}
AESTRACT
Geochemical exploration studies were undertaken in the Cripple Creek district to test the possibility that large low-grade gold deposits might be found. Surface rock samples taken throughout the district indicate that the volcanic rocks between the productive veins contain an average of about $0.6 \mathrm{ppm}$ (part per million) gold. In an area about 3,800 feet long and 500 feet wide near the Cresson mine in the south-central part of the district, scattered surface samples show that the rocks contain an average of 2.5 ppm gold, equivalent to $\$ 2.50$ per ton. Inasmuch as veins that contain more than $2.5 \mathrm{ppm}$ may also exist in the area, systematic sampling by trenching and drilling is warranted.
\end{abstract}

\section{N.IRODuction}

The famous Cripple Creek mining district, 20 miles southwest of Colorado Springs, Colo. (fig. 1), has produced about 21 million ounces of gold since its discovery in 1891. Value of this gold exceeds the total output from all other mining districts in the Front Range combined (Lovering and Goddard, 1950, p. 7). In the past decade, however, the last major mill and the last of the active mines were closed, threatening an end to the productive life of the district. As the mining potential of blocks of ground-as contrasted to that of veins alone-has not been extensively investigated, the Geological Survey recently began geochemical testing over the district as a whole, and the U.S. Bureau of Mines has made an engineering and economic study of the potential for large-scale surface mining operations in the district. This report pertains to the strongest and most extensive gold anomaly found during the geochemical investigation. A geochemical report on the entire district, giving all the analytical data, will be published later.

The investigations included a study of the distribution in surface rocks of gold, silver, tellurium, and mercury-elements commonly associated in gold deposits. The high mobility of mercury and tellurium apparently permits them to form a primary leakage halo above deposits of less mobile metals such as gold, and their geochemical distribution may therefore furnish clues to the distribution of gold and silver. At Cripple Creek, tellurium in particular was considered to be a potentially useful indicator because most of the gold in unoxidized ore occurs as tellurides. The recent development of sensitive analytical methoris and techniques for the determination of tellurium (Lakin and Thompson, 1963), mercury (Vaughn and McCarthy, 1964), silver (N a k g a w a and Lakin, 1965), and gold (Lakin and Nakagawa, 1965) makes it possible to study the geochemical distribution and abundance of these elements. The gold deposits have been descriked by Cross and Penrose (1895), Lindgren and Ransome (1906), Loughlin (1927), Loughlin and Koschmann (1935), Ko s chm an n (1949), and Lovering and Goddard (1950).

Acknowledgments. - It is a pleasure to acknowledge the warm cooperation of Max Bowen, President. and Charles Carlton, Manager of Mines, of the Golden Cycle Corp. The authors appreciate the assistance during the field investigations by Prof. Günther Friedrich, Professor of Geochemistry, Univer sity of Aa?hen, West Germany.

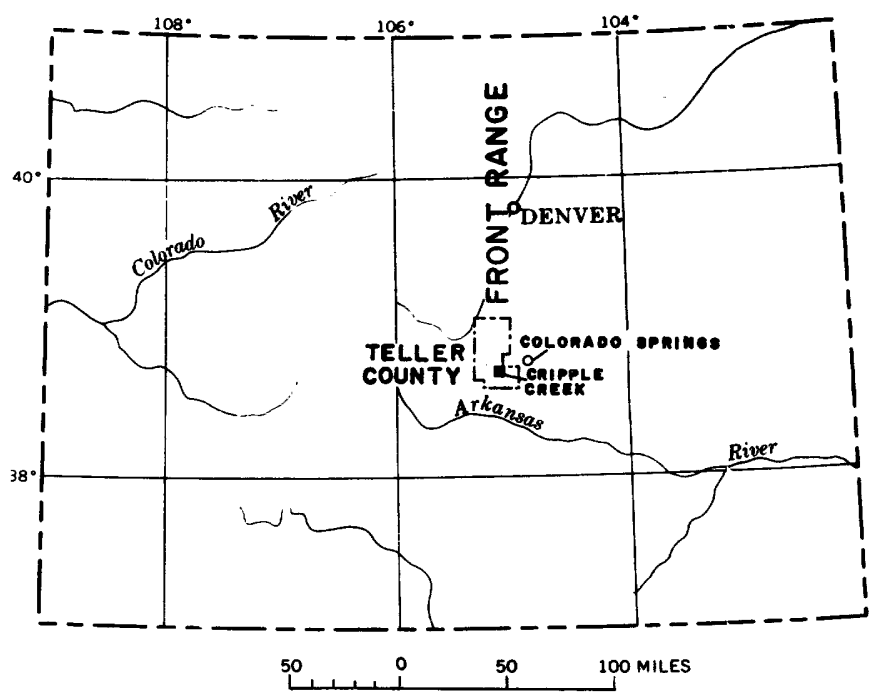

Figure 1.-Index map of Colorado showing area of this report. 


\section{GEOLOGK ENMRONMENT}

The gold deposits of the Cripple Creek district are largely confined to a roughly elliptical volcanic subsidence basin about 4 miles long and 2 miles wide that is surrounded by Precambrian granite, gneiss, and schist (fig. 2). The basin is filled with fractured and brecciated fragmental rocks, chiefly latite-phonolite and phonolite, of Tertiary (Miocene) age. Rocks of the basin are mainly volcanic near the surface but include increasing amounts of nonvolcanic material at depth. The volcanic rocks are intruded by dikes and ir regular masses of phonolite, latite-phonolite, trachyte, syenite, trachydolerite, vogesite, and monchiquite. Brecciation and fracturing were caused mostly by subsidence of the consolidated fragmental rocks in the basin and recurrent explosive eruptions. The ma jor fracture system trends generally north, and it is in these fractures that gold telluride ores were localized.

Investigations by Loughlin and.Koschmann (1935) indicate that the mineralizing solutions entered the volcanic complex through several channel ways and migrated upward and laterally through the main fissure zones. As these solutions ascended they spread outward into shallower subsidiary fracture zones. Most of the ore deposits are in the relatively shallow subsidiary fracture zones, but some of those within the main fissure zones continue to the deepest workings, 3,000 feet or more below the surface.

\section{MATERIAL SAMPLED}

Samples of bedrock are difficult to obtain in the district because outcrops are scarce and much ground is covered by mine dumps. Most samples were collected, therefore, from shallow pits that had been dug to bedrock by the early prospectors; sample locations are shown in figure 2. Many of these pits have been partially refilled by surficial debris during the years since they were dug, and at these the bedrock material on the dumps was sampled. The lack of bedrock exposures made it impossible to sample systematically, and consequently the set of samples may not be representative of all the bedrock. The analytical data presented here probably are lower than would be obtained if bedrock could have been sampled directly; the pits sampled were shallow presumably because they lacked any mineralized structures, such as small veins or joint surfaces, to lure the prospector onward.

\section{ANALYICAL PROCEDURES}

Gold was determined by a wet chemical method using atomic absorption spectrophotometry. The results obtained by this method are very close to those given by fire assay, as shown in the following table in which analyses of 10 samples by both methods are compared.

Analyses (ppm)

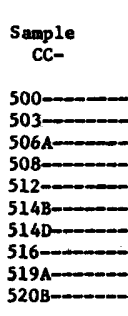

Atomic absorption (by Gordon H. VanSIckle)

$$
\begin{array}{r}
2.2 \\
.1 \\
3.3 \\
14.3 \\
6.2 \\
7.5 \\
4.6 \\
5.7 \\
7.4 \\
3.4
\end{array}
$$

Fire arsay (by 0. M. Parker

J. D. Mensik, and $\mathrm{Cl}$ mode Huf fman, Jr.)

2.0
.07
2.5
14.1
5.4
7.1
4.3
5.0
6.1
2.8

Tellurium was determined by a sensitive wet chemical method developed by Lakin and Thompson (1963). Silver was determined by a wet cromical catalytic method using atomic absorption; and mercury was determined instrumentally by an atomic absorption technique (Vaughn and McCarthy, 1964).

\section{ANOMMLUS APEA}

An extensive gold anomaly is show by the geochemical sampling in the vicinity of the Cresson mine in the SE/4 sec. 19, SW/4 sec. 20 , and NE/4 sec. 29. The area extends about 2,000 feet northw sstward and 2,000 feet southeastward from the Cresson mine. Within this area 2 to 5 samples were collected at each locality sampled. The average concentration of gold in samples at each locality is shown on figure 3 , and the highest concentration of gold, silver, tellurium, and mercury in samples at each locality is shown on figures 4,5 , 6 , and 7 , respectively. The area witr in which all samples contain at least $1 \mathrm{ppm}$ (part per million) gold is about 3,800 feet long and 500 feet wide. Average value (arithmetic) of 49 samples from witr in this area is 2.5 ppm gold (approx $\$ 2.50$ per ton); irdividual samples range from 1 to $14.5 \mathrm{ppm}$.

\section{DISTRIOUTION OF GOLD, SILVER, TELLURJUM, AND MERCURY}

Distribution patterns of gold, silver, and tellurium (figs. 3-6) are nearly identical in the anomalous area; the distribution of mercury (fig. 7) is similar but more restricted. The distribution pattern $\%$ of gold, silver, and tellurium probably reflect the distribution of gold and silver tellurides. Table 1 shows the average concentration and the enrichment above crustal abundance of the four metals. Although mercury-in the form of cinnabar-occurs locally in the district, it is not greatly enriched above crustal abundance in the area of this report. Tellurium and gold are grently enriched and silver is moderately so. The mercury in the goldbearing veins probably was emplaced during the waning and cooling stages of mineralization. Such an interpretation is strongly supported by the occurrence of late-stage cinnabar in the Cresson mine, where it locally coats the gold tellurides. 
Table 1.-Abundance of gold, silver, tellurium, and mercury in the earth's crust, in volcanic rocks of the entire Cripple Creek district, and in rocks of the area of the gold anomaly discussed in this report

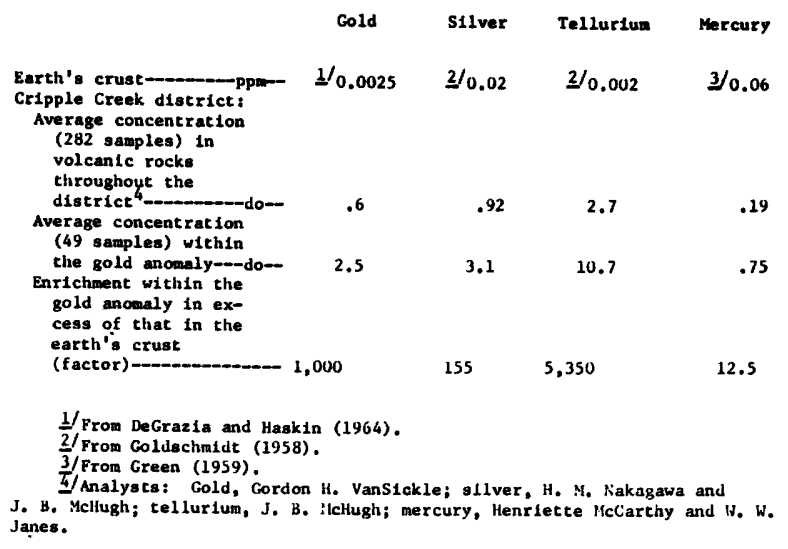

\section{ECONOMIC POTENTLA}

The Cripple Creek district has produced gold valued at nearly one-half billion dollars at the time of sale, and worth nearly three-quarters of a billion dollars at the present price. It seems unlikely that all the gold within the district has been extracted, but exploration and mining of veins similar to those that have been mined in the past probably would be prohibitively expensive. Because of this and because more gold has been mined from shallow deposits than from deep ones, the best possibility for the discovery and development of additional gold reserves within the district appears to be large low-grade deposits that can be mined by low-cost methods from the surface.

The anomalous area described in this report conceivably could constitute just such a deposit, particularly since the concentrations reported herein are thought to approach minable grade. The computed amount of rock within the anomalous area is about 15 million tons per 100 feet of depth; and if the aver age grade is $2.5 \mathrm{ppm}$ gold as the samples at the surface suggest, a mass of rock of this size would contain about $\$ 37.5$ million worth of gold. Inasmuch as the deepest mining within the district has reached 3,000 feet, the body of rock of this grade could reasonably be expected to extend to depths of at least sever a 1 hundred feet.

Whether or not the results of preliminary sampling reported here are representative of the gold content of a large body of rock, they identify an area sufficiently anomalous in gold to warrant systematic sampling, including such trenching or drilling as might be necessary to allow the sampling. Trenching would be required to obtain either grid or channel samples of the bedrock in much of the area, and angle dr:ll holes would be required to reach the bedrock beneath large dumps. The U.S. Bureau of Mines is currently planning such sampling in its program of research on $\varepsilon$ ampling of low-grade deposits.

\section{REFERENCES}

Cross, Whitman, and Penrose, R. A. F., Jr., 1895, Geology and mining industries of the Cripple Creek district, Colorado: U.S. Geol. Survey 16th Ann. Rept., pt. 2, p. 1-209.

DeGrazia, A. R., and Haskin, Larry, 1964, On the gold contents of rocks: Geochim. et Cosmochim. Acta, v. 28 , no. 5 , p. 559-564.

Goldschmidt, V. M., 1958, Geochemistry [ed. by Alex Muir]: London, Oxford Univ. Press, 730 p.

Green, Jack, 1959, Geochemical table of the 6 lements for 1959: Geol. Soc. America Bull., v. 70, p. 11271184.

Koschmann, A. H., 1949, Structural control of the gold deposits of the Cripple Creek district, Teller County, Colorado: U.S. Geol. Survey Bull. 955-B, p. $19-58$.

Lakin, H. W., and Nakagawa, H. M., 1965, A spectrophotometric method for the determiration of traces of gold in geologic materials, in Geological Survey research 1965: U.S. Geol. Survey Prof. Paper 525-C, p. C168-C171.

Lakin, H. W., and Thompson, C. E., 1963, Tellurium a new sensitive test: Science, v. 141, no. 3575 , p. $42-43$.

Lindgren, Waldemar, and Ransome, F. L., 19C' , Geology and gold deposits of the Cripple Creek district, Colorado: U.S. Geol. Survey Prof. Paper 54,516p.

Loughlin, G. F., 1927, Ore at deep levels in the Cripple Creek district, Colorado: Am. Inst. Miningr Metall. Engineers Tech. Pub. 13, 32 p.

Loughlin, G. F., and Koschmann, A. H., 1935, Geology and ore deposits of the Cripple Creek d ist $\mathrm{r}$ ict, Colorado: Colorado Sci. Soc. Proc., v. 13, no. 6, p. $217-435$.

Lovering, T. S., and Goddard, E. N., 1950, Geology and ore deposits of the Front Range, Colorado: U.S. Geol. Survey Prof. Paper 223, 319 p.

Nakagawa, H. M., and Lakin, H. W., 1965, A field method for the determination of silver in soils and rocks, in Geological Survey research 19:5: U.S. Geol. Survey. Prof. Paper 525-C, p. C172-C175.

Vaughn, W. W., and McCarthy, J. H., Jr., 1964, An instrumental technique for the determination of submicrogram concentrations of mercury in soils, rocks, and gas, in Geological Survey research 1964: U.S. Geol. Survey Prof. Paper 501-D, p. D123D127. 


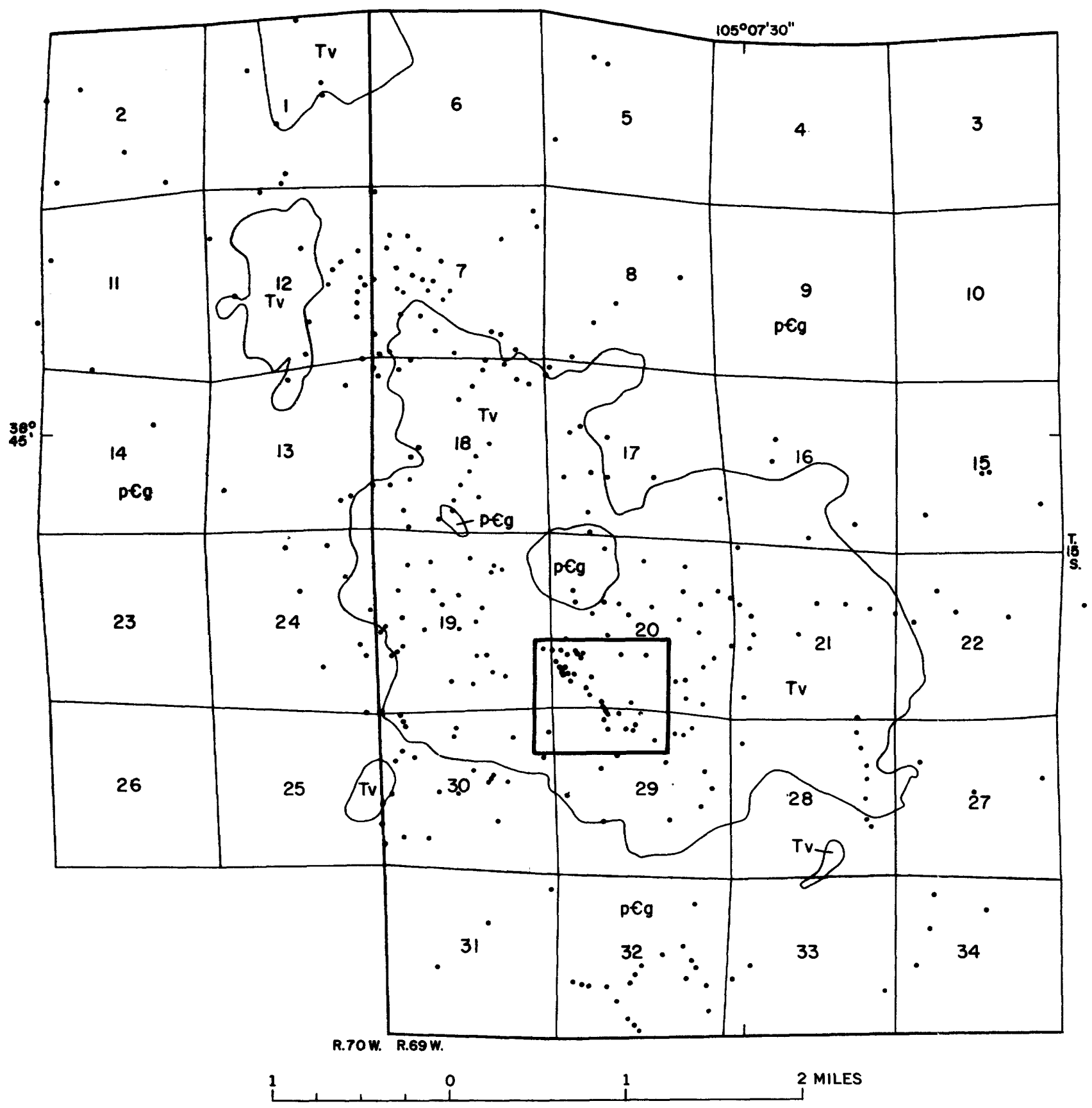

Figure 2.-Map showing sampled localities (dots) and area of figures 3-7 (heavy rectangle). Tv, Tertiary brecciated volcanic rocks; pco, Precambrian granite and some gneiss and schist. 


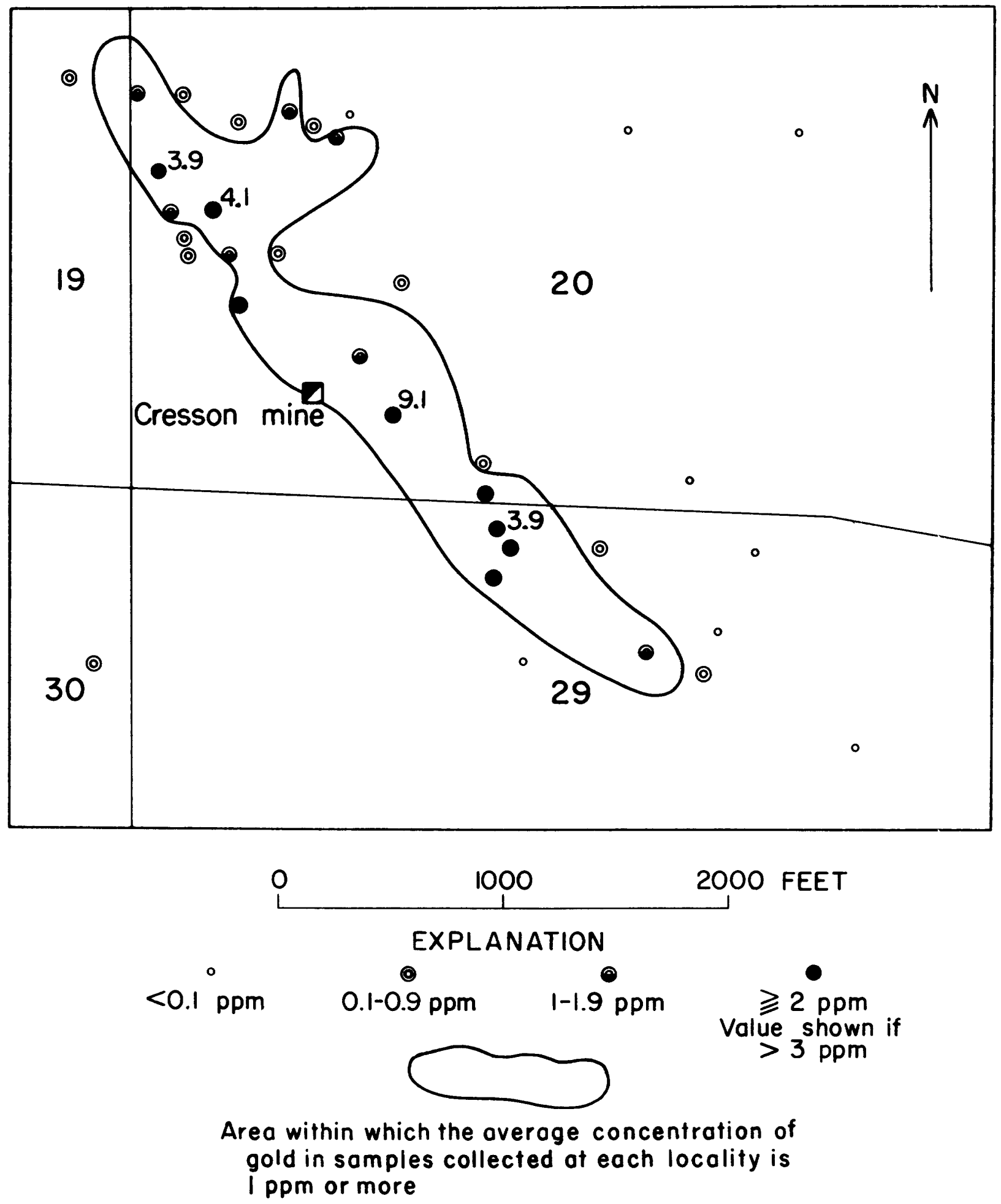

Figure 3.-Gold distribution, average concentration at each locality. 


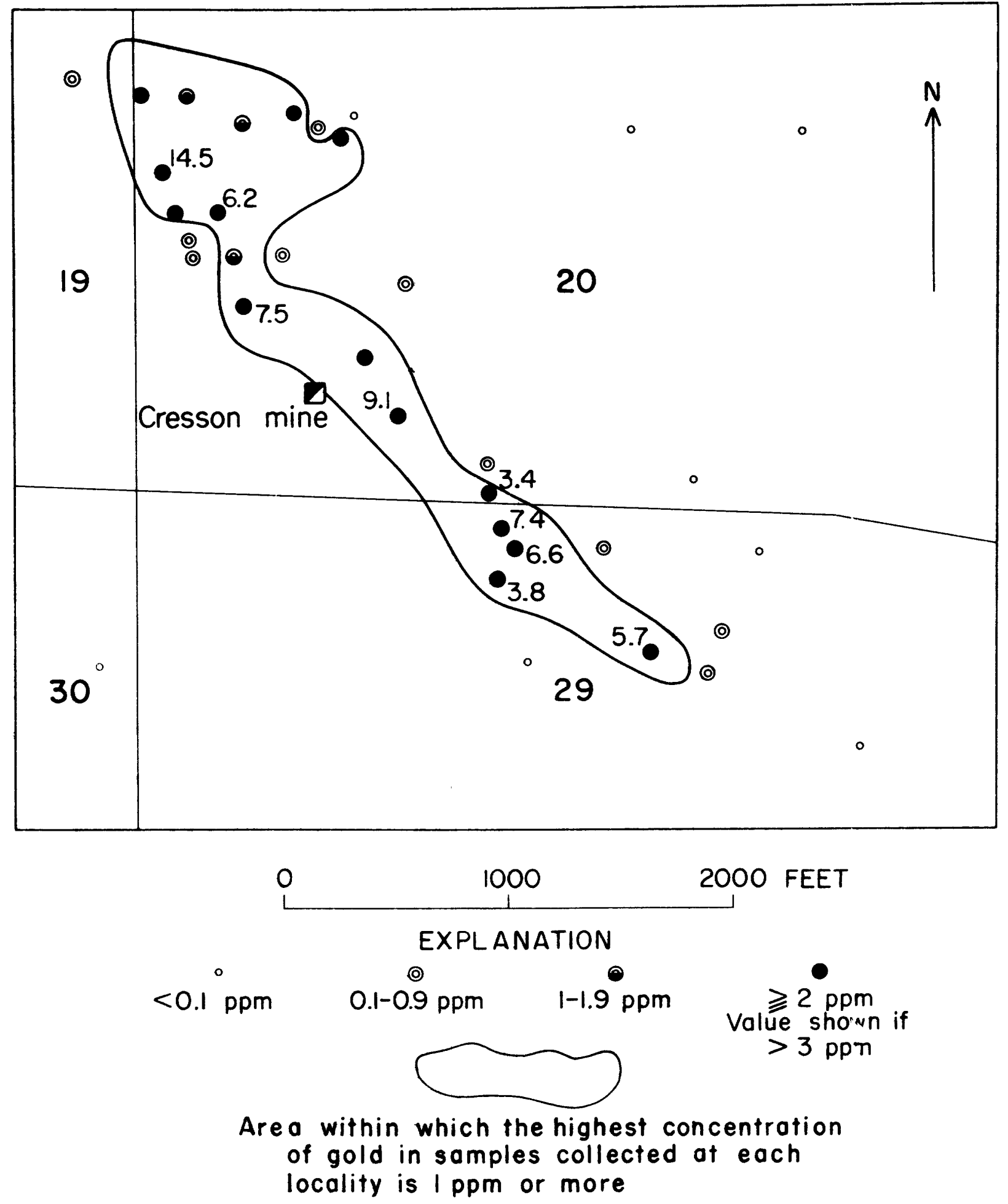

Figure 4.-Gold distribution, highest concentration at each locality. 


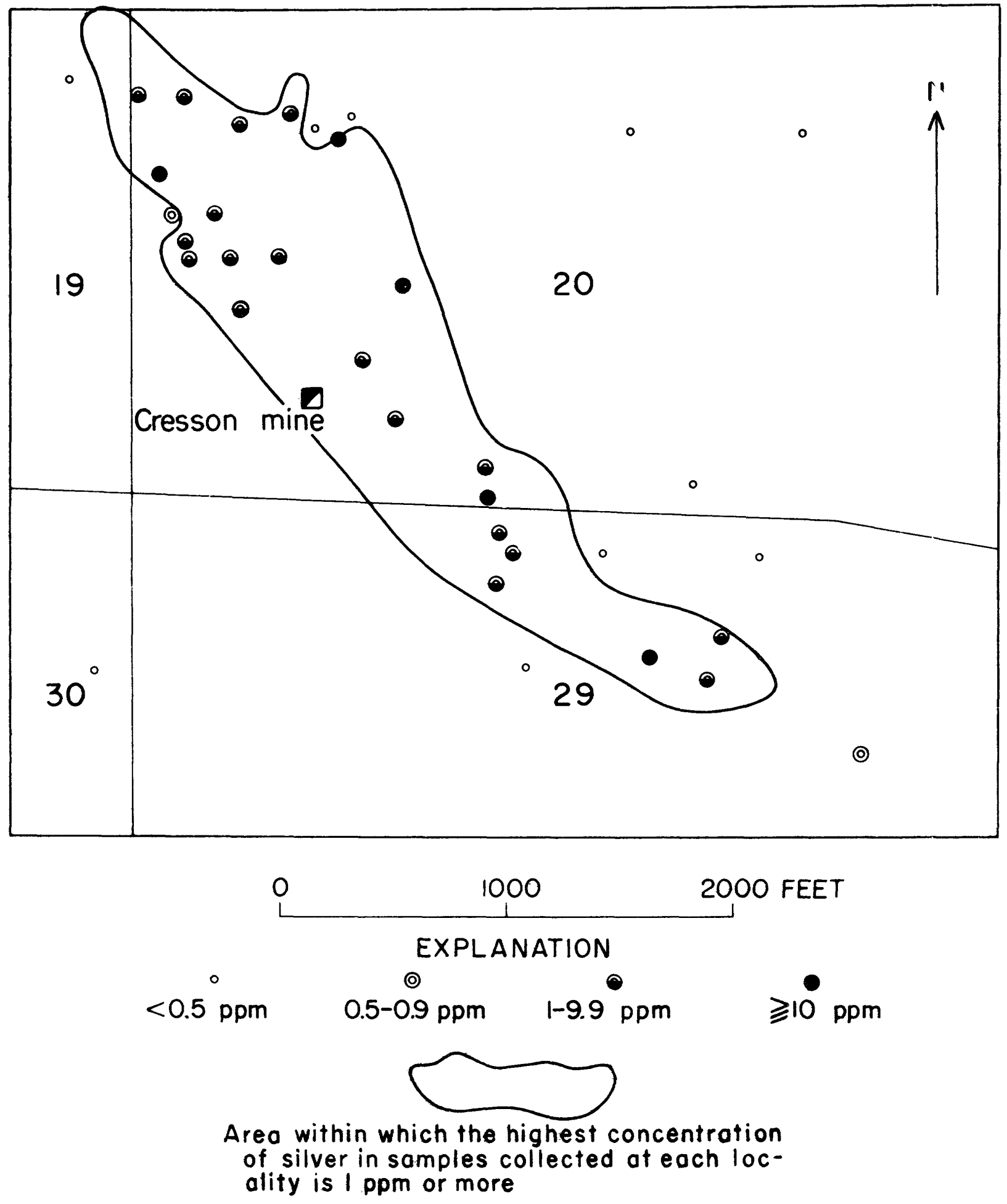

Figure 5.-Silver distribution, highest concentration at each locality. 


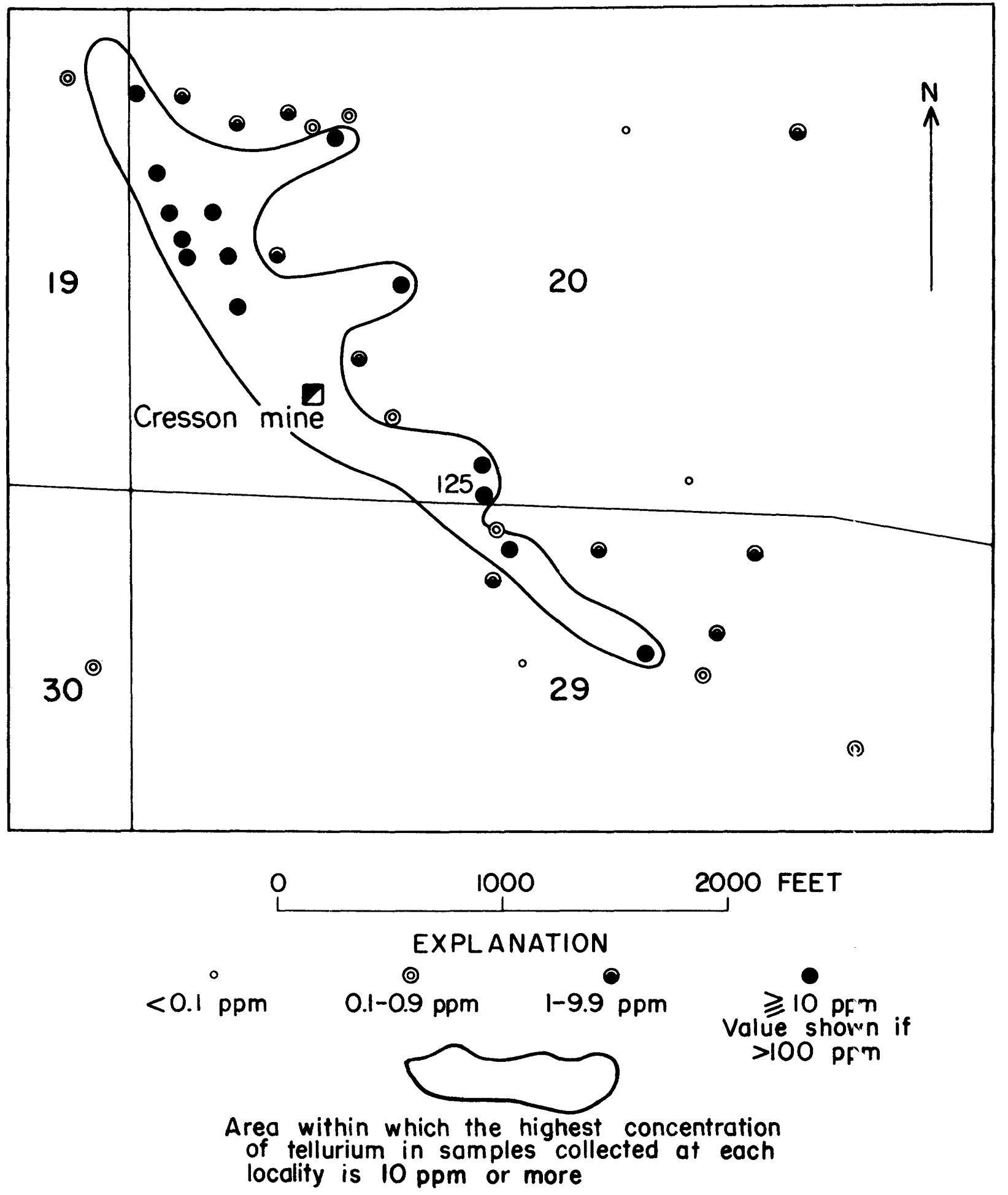

Figure 6.-Tellurium distribution, highest concentration at each locality. 


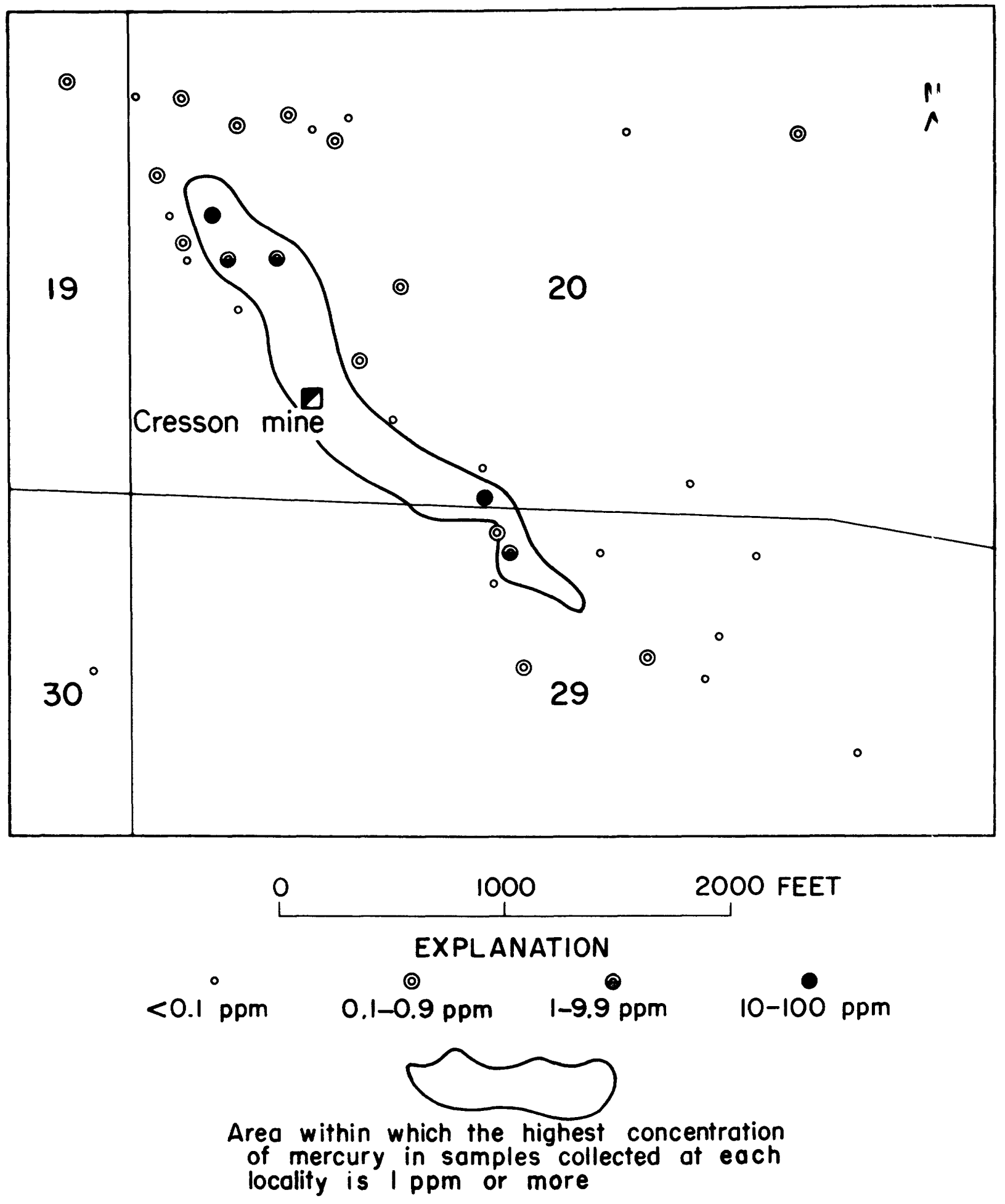

Figure 7.-Mercury distribution, highest concentration at each locality. 
